\title{
Characteristics of the phytoplankton community and bioaccumu- lation of heavy metals during algal blooms in Xiangjiang River (Hunan, China)
}

\author{
LI Jie $^{1}$, PENG FuLi ${ }^{2}$, DING DongBo ${ }^{1}$, ZHANG ShuBing $^{1}$, LI DeLiang $^{3} \&$ ZHANG Ting ${ }^{3 *}$ \\ ${ }^{1}$ School of Biological Science and Technology, Central South University, Changsha 410013, China; \\ ${ }^{2}$ Department of Ecology, China National Environmental Monitoring Centre, Beijing 100012, China; \\ ${ }^{3}$ College of Animal Science and Technology, Hunan Agriculture University, Changsha 410128, China
}

Received March 1, 2011; accepted May 25, 2011

\begin{abstract}
The frequency of algal blooms has increased in the mid and downstream reaches of the Xiangiiang River (Hunan, China), one of the most heavily polluted rivers in China. We identified the bloom-forming species in a bloom that occurred mid-late September 2010. In addition, we determined the extent of metal bioaccumulation in the algae and measured the toxicity of the algae using a mouse bioassay. Water samples were collected at upstream (Yongzhou), midstream (Hengyang), and downstream (Zhuzhou, Xiangtan, and Changsha) sites. The dominant species was Aulacoseira granulata, formerly known as Melosira granulata. The heaviest bloom occurred at Xiangtan and Changsha, where the number of A. granulata peaked at $1.3 \times 10^{5}$ filaments $\mathrm{L}^{-1}$ and chlorophyll $a$ at $0.04 \mathrm{mg} \mathrm{L}^{-1}$. Concentrations of $\mathrm{Al}, \mathrm{Fe}$, and $\mathrm{Mn}$ were $4.4 \times 10^{3}, 768.4$, and $138.7 \mathrm{mg} \mathrm{kg}^{-1} \mathrm{dry}^{-}$ weight in the phytoplankton. The bioaccumulation factor was $4.0 \times 10^{5}, 7.7 \times 10^{5}$, and $3.2 \times 10^{3}$, respectively. The heavy metal Pb had the greatest tendency to bioaccumulate among the highly toxic heavy metals, with a concentration of $19.2 \mathrm{mg} \mathrm{kg}^{-1} \mathrm{dry}$ weight and bioaccumulation factor of $9.6 \times 10^{3}$. The mouse bioassay suggested the bloom was toxic. The $\mathrm{LD}_{50} \mathrm{was} 384 \mathrm{mg} \mathrm{kg}^{-1}$ and all surviving mice lost weight during the first $72 \mathrm{~h}$ after exposure. Our results demonstrate that blooms of A. granulata in rivers contaminated with heavy metals pose a threat to freshwater ecosystems and human health. Thus, measures should be taken to control eutrophication and heavy metal pollution in such rivers.
\end{abstract}

Aulacoseira granulata, bioaccumulation, diatom bloom, heavy metal, Xiangjiang River

Citation: Li J, Peng F L, Ding D B, et al. Characteristics of the phytoplankton community and bioaccumulation of heavy metals during algal blooms in Xiangiiang River (Hunan, China). Sci China Life Sci, 2011, 54: 931-938, doi: 10.1007/s11427-011-4222-6

Occurrences of algal blooms have increased in frequency in the last decade and have become a significant problem throughout the world. In China, heavy blooms have been documented in a number of lakes, including Taihu Lake $\left(2340 \mathrm{~km}^{2}\right.$, the third largest freshwater lake), Chaohu Lake $\left(769.55 \mathrm{~km}^{2}\right)$, and Dianchi Lake $\left(309 \mathrm{~km}^{2}\right)$ [1-3], and several rivers, including the Hanjiang River, a major tributary of the Yangtze River [4,5]. In addition, these blooms persist over an extended period. For example, a diatom bloom per-

*Corresponding author (email: tingzh0517@163.com) sisted for approximately one month during 2010 in the Hanjiang River. Similarly, cyanobacterial blooms in Dianchi Lake often persisted throughout the year [2]. These long lasting algal blooms affect the appearance and quality of the water, thus decreasing the value of the water body for recreation, fishing, hunting, and aesthetic enjoyment. Furthermore, the blooms pose a risk for animal and human health and aquatic-ecosystem sustainability $[3,6,7]$.

Algal blooms may be toxic to aquatic animals and humans. A small percentage of algal species ( $>100$ currently identified) produce toxin chemicals, including 60 species of 
Cyanobacteria, 30 species of Dinophyta, and a few species of the genus Bacillariophyta, Chrysophyta, Rhodophyta, Phaeophyta, and Chlorophyta [8]. Contamination of the water used for kidney dialysis with microcystin resulted in 100 of 131 patients developing acute liver failure, leading to 52 deaths in Brazil in 1996 [9]. Given the health risk, it is critical to determine whether the dominant species in a bloom produces toxins. In addition, algae are able to bioaccumulate and bioconcentrate other toxic pollutants. Algal toxins and other toxic pollutants may be transferred to species of a higher trophic level, including human beings, and threaten the health of these animals [10].

Xiangjiang River is one of the primary tributaries of the Yangtze River. It has a total length of $856 \mathrm{~km}$, of which $670 \mathrm{~km}$ is within Hunan Province. The river flows from south to north through the following five administrative regions (in order from upstream): Yongzhou, Hengyang, Zhuzhou, Xiangtan, and Changsha. These regions constitute the center for politics, economics and culture, and are the most developed areas in Hunan Province $[11,12]$. Recently, algal blooms have occurred in the river throughout this region, particularly in mid-late October 2008 and late September 2010. The later bloom blocked the filters at the water treatment facility, causing a significant decrease in the supply of water to Changsha city due to decreased hydraulic pressure and flux. In addition, the water had an unappealing odor and posed a health risk. Despite the risk to human health, little is known about the bloom-forming species and phytoplankton community structure for these blooms. Furthermore, Xiangjiang River is subjected to heavy metal pollution. The bioaccumulation of heavy metals in phytoplankton increases the ecotoxicological risk to other aquatic organisms and local inhabitants. In the present study, therefore, our objectives were to (i) identify the bloom-forming species and phytoplankton community structure, (ii) measure the bioaccumulation of heavy metals in the phytoplankton, and (iii) assess the toxicity of the algal bloom and determine whether it poses a threat to freshwater ecosystems or human health.

\section{Materials and methods}

\subsection{Water sampling}

Water samples were collected at five sites on September 21 and 23, 2010, during the peak period of algal blooms. The sites were located upstream at Quhe Bridge in Yongzhou, midstream at Xiangjiang Gongtie Bridge in Hengyang, and downstream at Xiangjiang First Bridge in Zhuzhou, Xiangtan First Bridge in Xiangtan, and Yinpengling Bridge in Changsha (Figure 1). The samples were collected $0.5 \mathrm{~m}$ below the water surface and at least $5 \mathrm{~m}$ away from the riverbank using a stainless steel sampler. At each site we collected samples from three parallel sites that were perpendicular to both bank sides. The three samples were then mixed and placed in plastic bottles. We used $1 \mathrm{~L}$ of the sample for quantitative analysis of phytoplankton and the remaining water was used for quantifying levels of chlorophyll $a$ and metals. Samples of phytoplankton for qualitative identification were collected at the water surface using a $25^{\#}$ phytoplankton net. Lugol's solution (final concentration $1 \%$ ) was added immediately to the phytoplankton samples.

\subsection{Phytoplankton identification and biodiversity in- dex calculation}

The phytoplanktons were identified to the species level under a light microscope (Motic BA400, China) following the descriptions in The Freshwater Algae of China: Systematics, Taxonomy, and Ecology [13] and Chen and Li [14]. The samples were then digested by acid for accurate identification of the dominant species as follows. Two milliliters of sample was washed and centrifuged $(2000 \times g, 5 \mathrm{~min})$. We then added $0.5 \mathrm{~mL}$ concentrated sulfuric acid and five drops of nitric acid to digest the sample until the solution became transparent. After washing five times with distilled water by centrifugation $(2000 \times g, 5 \mathrm{~min})$, the residues were subject to scanning electron microscopy (HITACHI S-570, Japan).

We quantified biodiversity using the Shannon-Wiener index $[15,16]$. Values of $0-1$ indicate heavy pollution and 1-3 moderate pollution (within which 1-2 indicates $\alpha$-pollution and 2-3 $\beta$-pollution). Values $>3$ indicate light or no pollution.

\subsection{Phytoplankton counts and chlorophyll $a$ determi- nation}

The quantitative analysis of phytoplankton was conducted $24 \mathrm{~h}$ after collection. We gently mixed $50 \mathrm{~mL}$ of the settled sample and transferred $100 \mu \mathrm{L}$ to a slide. The number of the dominant species was counted under a standard light microscope (Motic BA400, China). Filaments with at least three cells were counted.

The concentration of chlorophyll $a$ was measured spectrophotometrically following extraction in $90 \%$ acetone by a freeze-thaw method according to the description in Methods for Water and Wastewater Analysis (4th edition) [17]. The sample was obtained by filtering at least $300 \mathrm{~mL}$ water through a $1.2 \mu \mathrm{m}$ Waterman GF-C membrane.

\subsection{Heavy metal analysis}

Both total and dissolved concentrations of metals in the water samples were measured. A $20 \mathrm{~mL}$ aliquot of water was filtered through a $0.45 \mu \mathrm{m}$ cellulose nitrate membrane for dissolved concentrations determination. All samples were collected in a polypropylene vial and acidified to $\mathrm{pH}<2$ with suprapur nitric acid (1\%). As, $\mathrm{Cd}, \mathrm{Cr}, \mathrm{Pb}, \mathrm{Al}, \mathrm{Fe}$, and $\mathrm{Mn}$ were measured using inductively coupled plasma-atomic emission spectrometry (ICP-AES, Intrepid II 


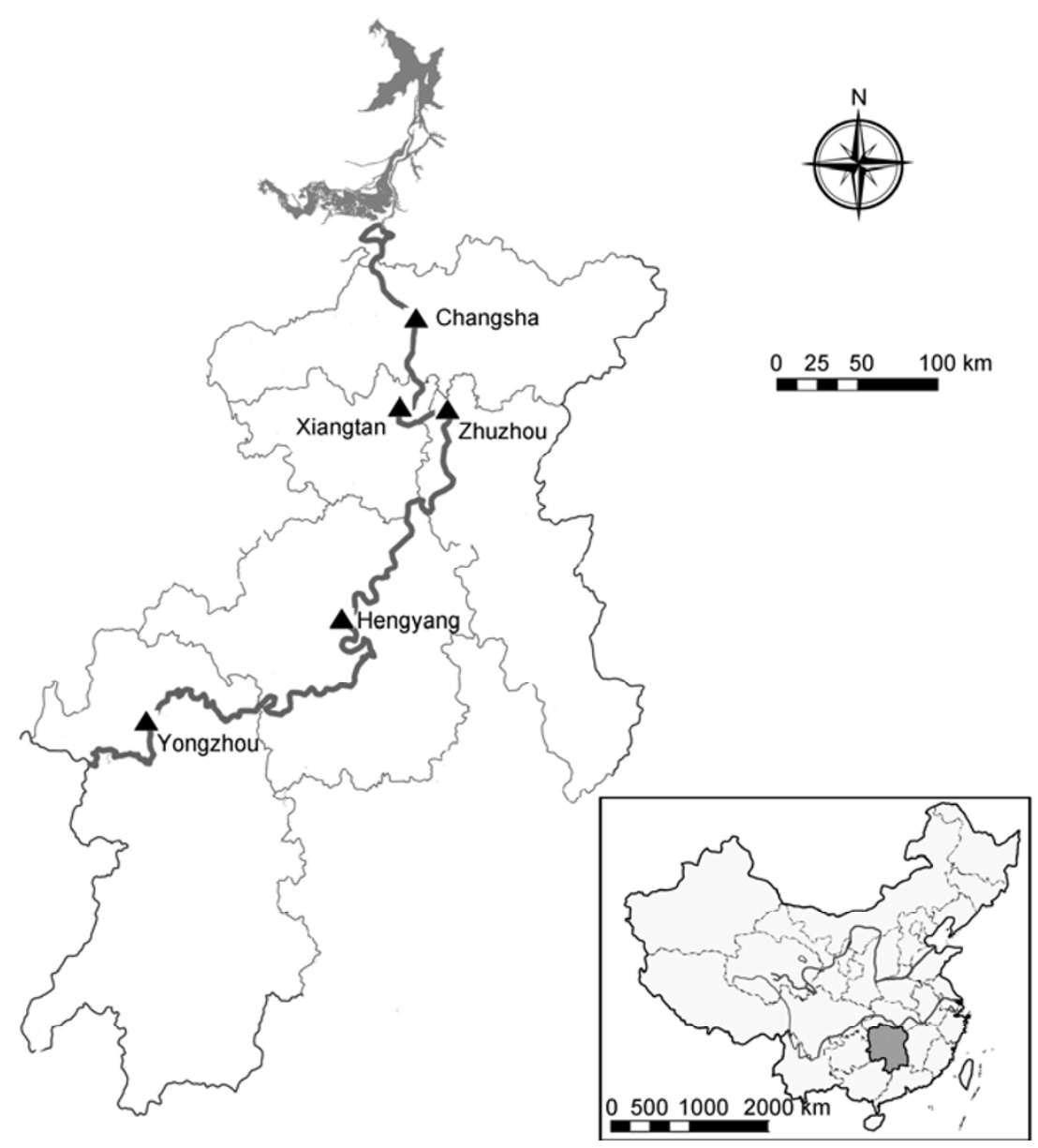

Figure 1 Study area and sites description in Xiangjiang River.

XSP, USA). This analysis was performed by the Analysis and Measurement Center, Central South University (Changsha, China). The detection limit for each of the metals was $3.0,0.1,0.4,2.0,1.2,0.3$, and $0.03 \mu \mathrm{g} \mathrm{L}^{-1}$, respectively. The Chinese standards for drinking water quality (GB 5749-2006) were referenced to assess whether the element reached levels that posed a risk to human health [18].

\subsection{Bioaccumulation}

To measure the bioaccumulation of heavy metals samples of phytoplankton collected at Changsha were used. The sample was settled and washed three times. Observation under a light microscope suggested that there was no sand or other suspended particle material in the water sample. The phytoplankton in the samples consisted primarily (95\%) of the dominant species. A $1 \mathrm{~g}$ aliquot of the sample was filtered through a pre-dried and pre-weighed $1.2 \mu \mathrm{m} \mathrm{GF-C} \mathrm{mem-}$ brane, which was then dried in an oven at $80^{\circ} \mathrm{C}$ for at least $48 \mathrm{~h}$ to obtain a constant weight for the dried samples. A second $1 \mathrm{~g}$ aliquot of the fresh sample was then processed by suprapur nitric acid digestion and filtered with the GF-C membrane before ICP-AES analysis. Bioaccumulation fac- tors were calculated by dividing metal (As, $\mathrm{Cd}, \mathrm{Cr}, \mathrm{Pb}, \mathrm{Al}$, $\mathrm{Fe}$, and $\mathrm{Mn}$ ) concentrations in the phytoplankton $\left(\mathrm{mg} \mathrm{kg}^{-1}\right.$ dry weight) by the dissolved concentrations of each metal in the water sample $\left(\mathrm{mg} \mathrm{kg}^{-1}\right)$. For samples in which the dissolved concentrations were lower than the limits of detection, the lower detection limits were used to represent the concentration of heavy metals.

\subsection{Mouse bioassay}

Mouse bioassay was performed following the methods in the acute toxicity test standard GB 15193.3-2003 [19] and the manual on harmful marine microalgae (second revised edition) [20]. Healthy male Kunming mice (weight 23-26 g) were obtained from Changsha Dongchuang Animal Science Service Department. A $26.4 \mathrm{~g}$ of fresh sample collected at the Changsha site was diluted to $30 \mathrm{~mL}$ with $0.9 \% \mathrm{NaCl}$. The diluted sample was then freeze-thawed six times and centrifuged $(8228 \times g, 3 \mathrm{~min})$. The toxicity of both the supernatant and the unextracted sample was tested. Dilutions of the supernatant and the unextracted sample were prepared over the following range in $0.9 \% \mathrm{NaCl}: 1,1 / 2,1 / 4$, $1 / 8,1 / 16$. The control group received $0.9 \% \mathrm{NaCl}$. An ali- 
quot of $0.9 \mathrm{~mL}$ was injected into three mice for each solution and we documented mortality and measured weight during the $72 \mathrm{~h}$ after injection.

\subsection{Statistical analysis}

To evaluate the distribution and bioaccumulation of metals in phytoplankton, differences between samples before and after filtration were analyzed using a paired $t$-test. Spearman correlation was conducted to determine the relationship between total metal concentrations and chlorophyll $a$. All the statistical analyses were performed with SPSS (Version 14.0, USA). A $P$-value of $\leqslant 0.05$ was considered to be significant.

\section{Results}

\subsection{Dominant species, phytoplankton composition and biomass}

The dominant species were long-chained cylindrical frustules, with golden-brown plastids arranged close to the periphery (Figure 2A). The terminal cell had 1-4 long spines around the margin of the valve (Figure 2A and B). Circular valves were about $20 \mu \mathrm{m}$ in diameter, flat without areolae (Figure 2C). The mantle had a length of 15-20 $\mu \mathrm{m}$, with 6-8 areolae per $10 \mu \mathrm{m}$. The areolae on the terminal cell were much coarser than those on other cells (Figure 2B). The short, linking spine had a triangular shape, terminating at the end of each costa (Figure 2D). Based on these characteristics, the species was identified as the centric diatom Aulacoseira granulata, formerly known as Melosira granulata.

A. granulata was most abundant $\left(1.3 \times 10^{5}\right.$ filaments $\left.\mathrm{L}^{-1}\right)$ in Changsha and Xiangtan (Figure 3A). The concentration

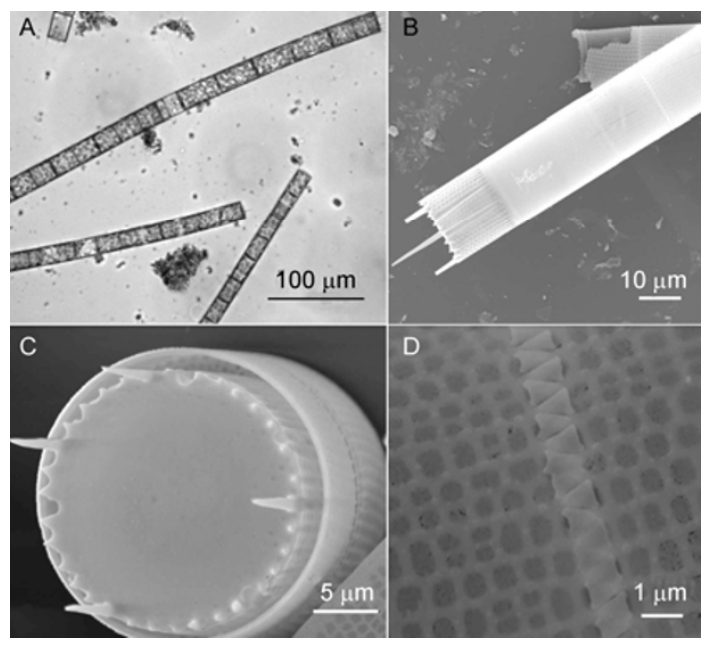

Figure 2 Photos of A. granulata under light microscopy (A), band (B), valve (C), and conjunction between cells (D) under electron microscopy. of chlorophyll $a$ peaked at 0.04 and $0.027 \mathrm{mg} \mathrm{L}^{-1}$, respectively, in these regions. In Zhuzhou, the maximum density of $A$. granulata was $0.5 \times 10^{5}$ filaments $\mathrm{L}^{-1}$. Conversely, at the upstream (Yongzhou) and midstream (Hengyang) sites, the density of A. granulata was $<1 \times 10^{3}$ filaments $\mathrm{L}^{-1}$ (Figure $3 \mathrm{~A}$ ) and chlorophyll $a$ concentrations were $5 \mu \mathrm{g} \mathrm{L}^{-1}$ (Figure 3B). Our results suggest that $A$. granulata bloomed in the downstream section of the river, primarily around Xiangtan and Changsha.

In Changsha, the species diversity of phytoplankton was low. The dominant species (A. granulata) accounted for more than $95 \%$ of the algal biomass. The remaining $5 \%$ consisted of three species of diatoms (Fragilaria, Bacillaria, Gyrosigm), six species of Chlorophyta, including one of Ulothrix, one of Scenedesmus, two of Pediastrum, and two of Eudorina, two species of Cyanobacteria, Oscillatoria and Microcystis, one species of Pyrrophyta, and one of Cryptophyta. The Shannon-Wiener index was 0.67 , indicating that the pollution was heavy. The species composition in Zhuzhou and Xiangtan was similar to that in Changsha. Though A. granulata was the dominant species in Yongzhou and Hengyang, its biomass was not sufficient to form a bloom. In Yongzhou, in addition to the species observed downstream, we found five species of diatoms, one each of $C y$ matopleura, Cymbella, and Amphora and two species of Gomphonema as well as two species of Chlorophyta, including one each of Oocystis and Oedogonium. No cyanobacteria Microcystis was found. The species biodiversity was significantly higher at the upstream site. The Shannon-Wiener index was 2.47 , indicating $\beta$-pollution, much lighter than the pollution in Changsha.

\subsection{Distribution and bioaccumulation of metals in Xiangjiang River}

Among the most toxic metals, the concentration of $\mathrm{Pb}$ was $0.035 \mathrm{mg} \mathrm{L}^{-1}$ in Zhuzhou. As levels exceeded $0.01 \mathrm{mg} \mathrm{L}^{-1}$ at all sites, except the upstream site at Yongzhou. The levels of these two metals exceeded the levels safe for drinking water based on the Chinese standard GB 5749-2006 (Table 1). Total concentrations of both $\mathrm{Cr}$ and $\mathrm{Cd}$ were below the drinking water criteria at all sites, and Cd levels were generally below the method detection limits (Table 1). Neither the concentrations before and after filtration nor the total concentrations among the up, mid, and downstream sites differed significantly $(P>0.05)$, with the exception of $\mathrm{Pb}$.

In contrast to the highly toxic metals, the levels of $\mathrm{Al}, \mathrm{Fe}$, and $\mathrm{Mn}$ increased gradually in a downstream direction. In Zhuzhou and Changsha, the levels of all three metals were higher than the safe drinking water limits, particularly in Zhuzhou where the concentrations of $\mathrm{Al}, \mathrm{Fe}$, and $\mathrm{Mn}$ were $0.37,0.538$, and $0.122 \mathrm{mg} \mathrm{L}^{-1}$, respectively. These levels were much higher than the safe levels of $0.2,0.3$, and 0.1 

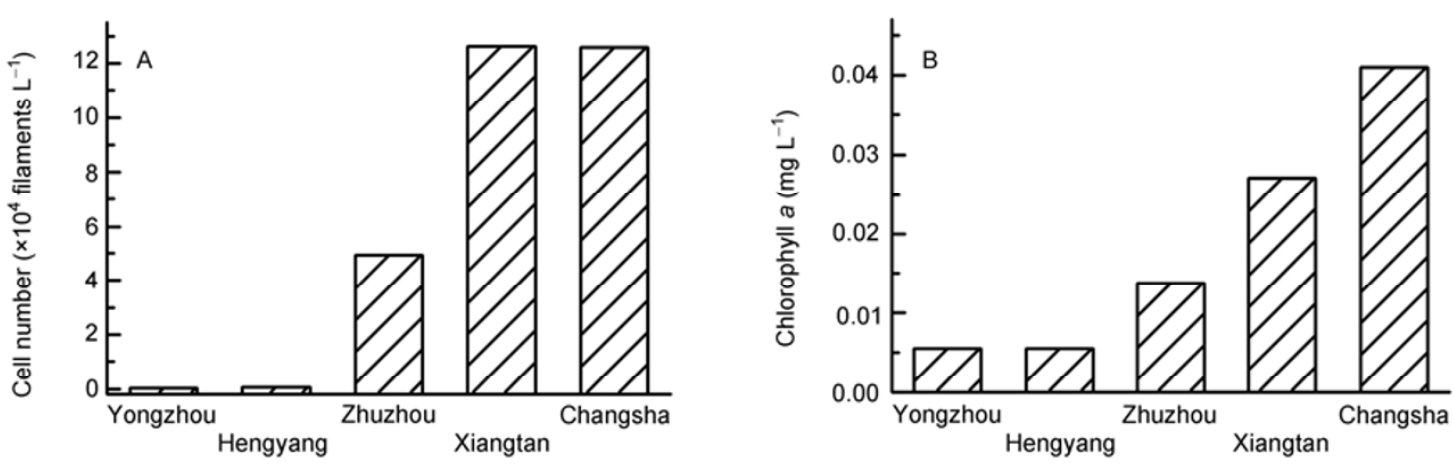

Figure 3 Number of A. granulata cells (A) and chlorophyll $a$ content (B) at different sites of Xiangiiang River.

Table 1 Metal concentrations in the surface water of Xiangjiang River before and after filtration with a $0.45 \mu \mathrm{m}$ nitrocellulose membrane and the bioaccumulation of metals in phytoplankton (unit: $\mathrm{mg} \mathrm{L}^{-1}$ )

\begin{tabular}{|c|c|c|c|c|c|c|c|c|}
\hline & & As & $\mathrm{Cd}$ & $\mathrm{Cr}$ & $\mathrm{Pb}$ & $\mathrm{Al}$ & $\mathrm{Fe}$ & $\mathrm{Mn}$ \\
\hline \multicolumn{2}{|c|}{$\begin{array}{l}\text { Levels risky to human health in } \\
\text { drinking water }\end{array}$} & 0.01 & 0.005 & 0.05 & 0.01 & 0.2 & 0.3 & 0.1 \\
\hline \multicolumn{2}{|c|}{ Detection limit of ICP-AES } & 0.003 & 0.0001 & 0.0004 & 0.002 & 0.0012 & 0.0003 & 0.00003 \\
\hline \multirow{2}{*}{ Yongzhou } & Before & $\mathrm{ND}$ & 0.001 & 0.008 & 0.006 & 0.069 & 0.054 & 0.032 \\
\hline & After & ND & $\mathrm{ND}$ & 0.005 & ND & 0.012 & 0.001 & 0.002 \\
\hline \multirow{2}{*}{ Hengyang } & Before & 0.014 & 0.001 & 0.006 & 0.006 & 0.039 & 0.048 & 0.022 \\
\hline & After & 0.014 & $\mathrm{ND}$ & 0.008 & ND & 0.008 & $\mathrm{ND}$ & ND \\
\hline \multirow{2}{*}{ Zhuzhou } & Before & 0.02 & ND & 0.01 & 0.035 & 0.372 & 0.538 & 0.122 \\
\hline & After & 0.018 & ND & 0.006 & $\mathrm{ND}$ & 0.033 & 0.024 & 0.062 \\
\hline \multirow{2}{*}{ Xiangtan } & Before & 0.013 & ND & 0.005 & ND & 0.278 & 0.277 & 0.07 \\
\hline & After & ND & ND & 0.007 & ND & 0.022 & 0.004 & 0.002 \\
\hline \multirow{2}{*}{ Changsha } & Before & 0.013 & 0.001 & 0.006 & ND & 0.326 & 0.36 & 0.153 \\
\hline & After & ND & ND & 0.005 & ND & 0.011 & 0.001 & 0.044 \\
\hline \multicolumn{2}{|c|}{$\begin{array}{l}\text { Concentration in phytoplankton } \\
\left(\mathrm{mg} \mathrm{kg}^{-1} \text { dry weight }\right)\end{array}$} & 4.210 & 0.789 & 5 & 19.2 & $4.4 \times 10^{3}$ & 768.4 & 138.7 \\
\hline \multicolumn{2}{|c|}{ Bioaccumulation factor } & $1.4 \times 10^{3}$ & $7.9 \times 10^{3}$ & $1.0 \times 10^{3}$ & $9.6 \times 10^{3}$ & $4.0 \times 10^{5}$ & $7.7 \times 10^{5}$ & $3.2 \times 10^{3}$ \\
\hline
\end{tabular}

a) ND, not detected.

$\mathrm{mg} \mathrm{L}^{-1}$ for these three elements (Table 1 ). The total concentrations of the three elements were significantly higher than the dissolved concentrations (Al, $P=0.037 ; \mathrm{Fe}, P=0.050 ; \mathrm{Mn}$, $P=0.020)$. Furthermore, the concentrations of these elements were correlated to the concentrations of chlorophyll $a$ at all sites except Zhuzhou (correlation coefficient=0.949, $P=0.051)$.

Phytoplankton tended to primarily accumulate $\mathrm{Al}$ and Fe. The content of these two metals was $4.4 \times 10^{3}$ and $768.4 \mathrm{mg}$ $\mathrm{kg}^{-1}$ dry weight and the bioaccumulation factors were $4.0 \times 10^{5}$ and $7.7 \times 10^{5}$, respectively (Table 1 ). Mn had a lower tendency to bioaccumulate in phytoplankton, with a content of $138.7 \mathrm{mg} \mathrm{kg}^{-1}$ and a bioaccumulation factor $3.2 \times 10^{3}$. Among the highly toxic heavy metals, $\mathrm{Pb}$ was accumulated more often than $\mathrm{Cd}, \mathrm{Cr}$, and As. The concentration of $\mathrm{Pb}$ was $19.2 \mathrm{mg} \mathrm{kg}^{-1}$ dry weight and the bioaccumulation factor was $9.6 \times 10^{3}$. As was accumulated at a lower rate, with a concentration of $4.2 \mathrm{mg} \mathrm{kg}^{-1}$ dry weight and a bioaccumulation factor of $1.4 \times 10^{3}$.

\subsection{Mouse bioassay}

All the mice treated with supernatant were less energetic and lost weight in the first $24 \mathrm{~h}$, except the mice injected with 1/16th dose of supernatant. All mice had recovered their weight by $72 \mathrm{~h}$ (Figure 4A). We did not observe any mortality in the mice that were injected with supernatant. In contrast, a number of mice that were injected with the unextracted sample died. All the mice injected with the undiluted solution or the $1 / 2$ strength dilution died within 24 h. Furthermore, one of the mice that received the undiluted solution died in the first $6 \mathrm{~h}$. Two mice in the 1/4 strength group and one in the $1 / 8$ th strength group died within $36 \mathrm{~h}$. There was no mortality in the group given a $1 / 16$ th dilution. All the mice lost weight in the first $24 \mathrm{~h}$ and did not recover their initial weight by $72 \mathrm{~h}$ (Figure $4 \mathrm{~B}$ ). The $\mathrm{LD}_{50}$ value was $384 \mathrm{mg} \mathrm{kg}^{-1}$ with a standard error of $\log$ transformed value of 0.12 and a $95 \%$ confidence interval of between 228.5-646.3 $\mathrm{mg} \mathrm{kg}^{-1}$. 

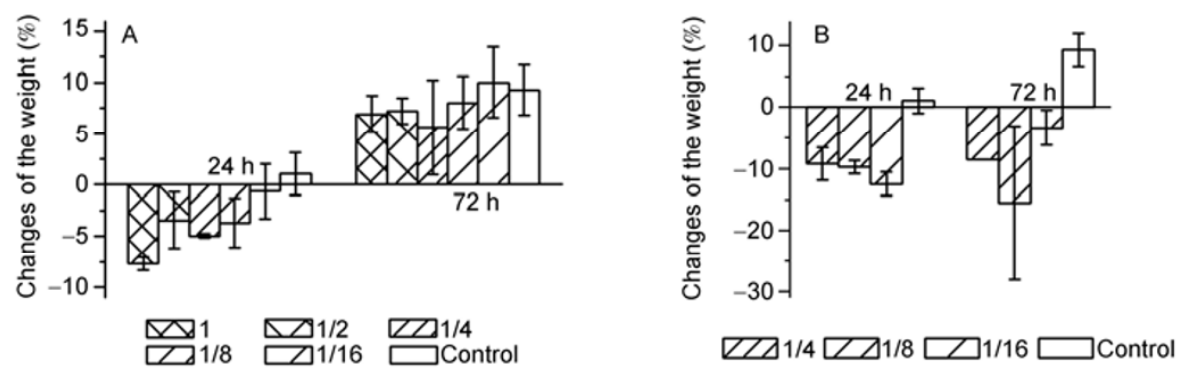

Figure 4 Effect of injecting the supernatant (A) and the unextracted sample (B) of phytoplankton on mouse weight.

We compared the differences in metal concentrations between the unextracted sample and the supernatant. The concentrations of $\mathrm{Al}, \mathrm{Fe}$, and $\mathrm{Mn}$ were $269.9,46.7$, and 8.4 $\mathrm{mg} \mathrm{L}^{-1}$ in the complete sample. These were 163,53 , and seven times higher, respectively, than those in the supernatant. In addition, the heavy metal $\mathrm{Pb}$ was $1.2 \mathrm{mg} \mathrm{L}^{-1}$ in the complete sample but undetectable in the supernatant. There was no difference in the concentration of the other metals between the complete sample and the supernatant.

\section{Discussion}

Prior studies of the Xiangjiang river have often emphasized the problems of heavy metal pollution $[12,21]$. In our research, the concentrations of $\mathrm{As}, \mathrm{Pb}, \mathrm{Al}, \mathrm{Fe}$, and $\mathrm{Mn}$ in the water near Zhuzhou surpassed the levels safe for drinking water. However, heavy metal pollution has decreased gradually since 2002 [11], which is reflected in our observation that the levels of $\mathrm{Cd}, \mathrm{Cr}$, and $\mathrm{Pb}$ were close to the drinking water criteria at most sites. Xiangjiang River has become eutrophic, particularly in the downstream sections near Zhuzhou, Xiangtan, and Changsha, due to increasing wastewater and agricultural pollution [22]. Total phosphorus and ammonia-nitrogen are the two major factors controlling water quality in the Xiangjiang River [11]. A. granulata is a classical indictor of eutrophic waters. It is often the dominant species in eutrophic freshwater areas around the world [23-25]. In our study, the total abundance of A. granulata was $1.3 \times 10^{5}$ filaments $\mathrm{L}^{-1}$ at Xiangtan and Changsha, which is comparable to levels in other studies [24] and close to the level $\left(3.15 \times 10^{5}\right.$ filaments $\left.\mathrm{L}^{-1}\right)$ reported in the Pearl River in China [24]. Thus, our data suggest that the Xiangjiang River is experiencing rapid eutrophication.

Diatoms are one of the main primary producers in aquatic ecosystems. They are considered to be passive participants in energy transfer in the food webs, being heavily grazed by their predators and exhibiting little or no anti-grazing capacity [26]. A number of diatom species produce the potent neurotoxin domoic acid, including Pseudonitzschia, Nitzschia, and Amphora [10]. However, most diatoms are thought to be beneficial to the growth and survival of marine and freshwater organisms, and to the trans- fer of organic material through the food chain to top consumers and important fisheries. Of note in this region, the diatom Stephanodiscus, responsible for blooms in Hanjiang River, was also reported to be non-toxic $\left(\mathrm{LD}_{50}>10 \mathrm{~g} \mathrm{~kg}^{-1}\right.$ for mice) [5,27]. Recently however, researchers have noted that copepods, the principal predators of diatoms, that feed on certain diatoms produce abnormal eggs that either fail to develop to hatching or hatch into malformed (i.e., teratogenic) nauplii that die soon afterwards [28,29]. The cytotoxic compounds responsible for these effects are short chain polyunsaturated aldehydes (PUAs) and other oxygenated fatty acid degradation products [29,30]. They are cleaved from fatty acid precursors by enzymes that activate within seconds after crushing of cells [29]. The known PUA producing species include many common species, such as Melosira, Odontella, Phaeodactylum, Rhizosolenia, Skeletonema, Stephanopyxis, and Thalassiosira. Studies on other sources of PUAs suggest that they induce cellular toxicity in the liver, kidney, stomach, and lung [31]. They react with DNA and thus there are increasing concerns for a potential link between aldehydes and development of cancer [32]. However, there have been no reports of aldehyde induced death. In the present study, we speculate that PUAs contributed to the loss of body weight in the first $24 \mathrm{~h}$ in the group injected with supernatant. The group injected with unextracted water samples had an $\mathrm{LD}_{50}$ of $384 \mathrm{mg} \mathrm{kg}^{-1}$, which is higher than the $\mathrm{LD}_{50}$ for Microcystis (7.3-14.4 mg kg-1) [33-35]. The time to death (6-48 h) was also longer than for mortality caused by microcystins and other cyanotoxins $[36,37]$. Given the significantly higher concentrations of $\mathrm{Al}$, $\mathrm{Fe}, \mathrm{Mn}$, and $\mathrm{Pb}$ in the unextracted sample, we conclude that the bioaccumulation of metals in the phytoplankton contributed to the mortality of the mice.

Algae possess a range of unique structures and physiological characters which give them a high tolerance to the accumulation of metals [38]. They have functional groups in the cell wall and extracellular components to reduce metal bioavailability. Some peptides and proteins chelate and sequester metals. In addition, the metabolic processes compartmentalize metals into a vacuole [38]. Our data suggest that $\mathrm{Al}$ is the most readily bioaccumulated metal. We documented levels of $4.4 \times 10^{3} \mathrm{mg} \mathrm{kg}^{-1}$ dry weight, which was higher than Al levels $\left(1.5 \times 10^{3}-2.0 \times 10^{3} \mathrm{mg} \mathrm{kg}^{-1}\right)$ in phyto- 
plankton in the non-polluted lake Rostherne Mere, UK, where Aulacoseira and other diatoms are co-dominate [39]. The differences may be due to the concentration in the water. Studies have shown a strong correlation between the concentration of metals in the water and in algae. For ex-

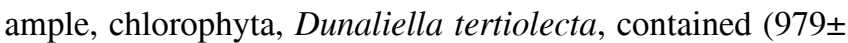
236) $\mathrm{mg} \mathrm{kg}^{-1} \mathrm{Al}$ at water concentrations of $0.5 \mathrm{mg} \mathrm{L}^{-1}$. This increased to $(1505 \pm 162) \mathrm{mg} \mathrm{kg}^{-1}$ at water concentrations of $1.0 \mathrm{mg} \mathrm{L}^{-1}$ [40]. Bioaccumulation of $\mathrm{Pb}$ is also of concern as $\mathrm{Pb}$ exhibits a high degree of toxicity to living organisms. Adverse effects of $\mathrm{Pb}$ exposure have been noted in the brain, blood, kidney, cardiovascular, and reproduction system $[41,42]$. In our research, $\mathrm{Pb}$ levels in phytoplankton peaked at $19.2 \mathrm{mg} \mathrm{kg}^{-1}$ dry weight with a bioaccumulation factor $9.6 \times 10^{3}$. However, the bioaccumulation factor may in fact be higher than what we measured as levels were almost undetectable in the water. Other studies have suggested that the bioaccumulation of $\mathrm{Pb}$ may be $2-4$ times greater than for $\mathrm{Al}$ [40]. In Toulon Bay, France, the bioaccumulation of $\mathrm{Pb}$ by phytoplankton varied between seasons. The lowest value was 48 , but peaked at $1.6 \times 10^{4}$, which is $67 \%$ higher than the value observed in our study [43].

In conclusion, blooms of $A$. granulata in the Xiangjiang River bioaccumulate high levels of $\mathrm{Al}, \mathrm{Fe}$, and $\mathrm{Pb}$. Inadvertently consuming these phytoplankton during a bloom represents a high risk to human and aquatic animal health. Given these risks, measures should be taken to control eutrophication and heavy metal pollution in this river.

We thank Li ZhenAn from Central South University for help with sample collection, Li Jie, Wang XingMing, and Guo HongShan for assistance with the mouse bioassay, and Cao Can for determination of metal concentrations. We also thank Dr. Xie LingTian from North Carolina State University for assistance with editing of the English. This work was supported by the National Natural Science Foundation of China (Grant Nos. 31000179 and 31000183).

1 Chen Y, Qin B, Teubner K, et al. Long-term dynamics of phytoplankton assemblages: Microcystis-domination in Lake Taihu, a large shallow lake in China. J Plankton Res, 2003, 25: 445-453

$2 \mathrm{Wu} \mathrm{W} \mathrm{J,} \mathrm{Li} \mathrm{G} \mathrm{B,} \mathrm{Li} \mathrm{D} \mathrm{H,} \mathrm{et} \mathrm{al.} \mathrm{Temperature} \mathrm{may} \mathrm{be} \mathrm{the} \mathrm{dominating}$ factor on the alternant succession of Aphanizomenon flosaquae and Microcystis aeruginosa in Dianchi Lake. Fresen Environ Bull, 2010, 19: 846-853

3 Qu J, Fan M. The current state of water quality and technology development for water pollution control in China. Crit Rev Env Sci Tec, 2010, 40: 519-560

4 Zeng H, Song L, Yu Z, et al. Distribution of phytoplankton in the Three-Gorge Reservoir during rainy and dry seasons. Sci Total Environ, 2006, 367: 999-1009

5 Zheng L L, Song L R, Wu X H, et al. Analysis of morphology and 18S rDNA gene from the causative specie related diatom bloom in Hanjiang River. Acta Hydrobiol Sin, 2009, 33: 562-564

6 Oberholster P J, Botha A M, Ashton P J. The influence of a toxic cyanobacterial bloom and water hydrology on algal populations and macroinvertebrate abundance in the upper littoral zone of Lake Krugersdrift, South Africa. Ecotoxicology, 2009, 18: 34-46

7 Carmichael W W. The toxins of cyanobacteria. Sci Am, 1994, 270: 64-70
8 Wang Z J. Drinking Water Safety Assessment. Beijing: Chemical Industry Press, 2008. 92-122

9 Azevedo S M F O, Carmichael W W, Jochimsen E M, et al. Human intoxication by microcystins during renal dialysis treatment in $\mathrm{Ca}$ ruaru-Brazil. Toxicology, 2002, 181: 441-446

10 Lefebvre K A, Robertson A. Domoic acid and human exposure risks: A review. Toxicon, 2010, 56: 218-230

11 Zhang Z, Tao F, Du J, et al. Surface water quality and its control in a river with intensive human impacts-a case study of the Xiangjiang River, China. J Environ Manage, 2010, 91: 2483-2490

12 Guo Z, Song J, Xiao X, et al. Spatial distribution and environmental characterization of sediment-associated metals from middle-downstream of Xiangjiang River, southern China. J Cent South Univ T, 2010, 17: $68-78$

$13 \mathrm{Hu} \mathrm{H} \mathrm{J}$, Wei Y X. The Freshwater Algae of China: Systematics, Taxonomy And Ecology. Beijing: Science Press, 2006. 304-308

14 Chen Y W, Li P F. Clarification for modifying 3 common phytoplankton genera names. J Lakes Sci, 2003, 15: 85-94

15 Belaoussoff S, Kevan P G, Murphy S, et al. Assessing tillage disturbance on assemblages of ground beetles (Coleoptera: Carabidae) by using a range of ecological indices. Biodivers Conserv, 2003, 12: 851-882

16 Zhang T, Li L, Song L R. Annual dynamics of phytoplankton abundance and community structure in the Xionghe Reservoir. Acta Ecol Sin, 2009, 29: 2971-2979

17 Ministry of Environmental Protection of the People's Republic of China. Determination methods for examination of water and wastewater (4th edition). Beijing: China Environmental Science Press, 2002. 223-671

18 Ministry of Public Health of the People's Republic of China and the China Standardization Administration. GB 5749-2006 Standards for drinking water quality. 2006

19 Ministry of Public Health of the People's Republic of China and the China Standardization Administration. GB-15193.3-2003 Acute toxicity test. 2003

20 Hallegraeff G M, Anderson D M, Cembella A D. Manual on harmful marine microalgae ( second revised edition). Paris: UNESCO Publishing, 2003: 270-274

21 Zhang Q, Li Z, Zeng G, et al. Assessment of surface water quality using multivariate statistical techniques in red soil hilly region: a case study of Xiangjiang watershed, China. Environ Monit Assess, 2009, 152: $123-131$

22 Chen Y S, Wu F C, Lu H Z, et al. Analysis on the water quality changes in the Xiangjiang River from 1981-2000. Resour Environ Yangtze Basin, 2004, 13: 508-512

23 Gibson C, Anderson J, Haworth E. Aulacoseira subarctica: taxonomy, physiology, ecology and palaeoecology. Eur J Phycol, 2003, 38: 83-101

24 Wang C, Li X, Lai Z, et al. Seasonal variations of Aulacoseira granulata population abundance in the Pearl River Estuary. Estuar Coast Shelf S, 2009, 85: 585-592

25 Kuang Q J, Zhang J Y. On the phytoplankton in the middle and lower reaches of the Hanjiang river and the prevention of water-blooms. Resour Environ Yangtze Basin, 2000, 9: 63-70

26 Caldwell G S. The influence of bioactive oxylipins from marine diatoms on invertebrate reproduction and development. Mar Drugs, 2009, 7: 367-400

27 Zeng Z, Qiu X, Chen K, et al. Acute toxicity examination and Ames test of raw water in Hanjiang River for diatoms. Water Wastewater Eng, 2004, 30: 5-6

28 Wichard T, Gerecht A, Boersma M, et al. Lipid and fatty acid composition of diatoms revisited: rapid wound-activated change of food quality parameters influences herbivorous copepod reproductive success. ChemBioChem, 2007, 8: 1146-1153

29 Ianora A, Miralto A. Toxigenic effects of diatoms on grazers, phytoplankton and other microbes: a review. Ecotoxicology, 2010, 19: 493-511

30 Leflaive J, Ten-Hage L. Chemical interactions in diatoms: role of polyunsaturated aldehydes and precursors. New Phytol, 2009, 184: 
794-805

31 Chang L W, Lo W S, Lin P. Trans,trans-2,4-decadienal, a product found in cooking oil fumes, induces cell proliferation and cytokine production due to reactive oxygen species in human bronchial epithelial cells. Toxicol Sci, 2005, 87: 337-343

32 Young S C, Chang L W, Lee $\mathrm{H} \mathrm{L}$, et al. DNA damages induced by trans,trans-2,4-decadienal (tt-DDE), a component of cooking oil fume, in human bronchial epithelial cells. Environ Mol Mutagen, 2010, 51: 315-321

33 Oishi S, Watanabe M F. Acute toxicity of Microcystis aeruginosa and its cardiovascular effects. Environ Res, 1986, 40: 518-524

34 Nakano M, Nakano Y, Saito-Taki T, et al. Toxicity of Microcystis aeruginosa K-139 strain. Microbiol Immunol, 1989, 33: 787-792

35 Ohtake A, Shirai M, Aida T, et al. Toxicity of Microcystis species isolated from natural blooms and purification of the toxin. Appl Environ Microb, 1989, 55: 3202-3207

36 Willén T, Mattsson R. Water-blooming and toxin-producing cyanobacteria in Swedish fresh and bracish waters, 1981-1995. Hydrobiologia, 1997, 353: 181-192

37 Andrinolo D, Pereira P, Giannuzzi L, et al. Occurrence of Microcystis aeruginosa and microcystins in Río de la Plata river (Argentina).
Acta Toxicol Argent, 2007, 15: 8-14

38 Zhou W B, Qiu B S. Mechanisms for heavy metal detoxification and tolerance in algae. J Lakes Sci, 2004, 16: 265-272

39 Quiroz-Vázquez P, White K N, Sigee D C. Aluminium, silicon and transition metal dynamics in a non-polluted lake: aquatic concentrations and phytoplankton uptake. Hydrobiologia, 2008, 607: 131-142

40 Türker Sacan M, Akmehmet Balcioglu I. Bioaccumulation of aluminium in Dunaliella tertiolecta in natural seawater: aluminium-metal $(\mathrm{Cu}$, $\mathrm{Pb}, \mathrm{Se}$ ) interactions and influence of $\mathrm{pH}$. B Environ Contam Tox, 2001, 66: 214-221

41 Maiti A K, Saha N C, Paul G. Effect of lead on oxidative stress, $\mathrm{Na}^{+}$ $\mathrm{K}^{+}$ATPase activity and mitochondrial electron transport chain activity of the brain of Clarias batrachus L. B Environ Contam Tox, 84: 672-676

42 Massanyi P, Lukac N, Makarevich A V, et al. Lead-induced alterations in rat kidneys and testes in vivo. J Environ Sci Heal A, 2007, 42: 671-676

43 Rossi N, Jamet J L. In situ heavy metals (copper, lead and cadmium) in different plankton compartments and suspended particulate matter in two coupled Mediterranean coastal ecosystems (Toulon Bay, France). Mar Pollut Bull, 2008, 56: 1862-1870

Open Access This article is distributed under the terms of the Creative Commons Attribution License which permits any use, distribution, and reproduction in any medium, provided the original author(s) and source are credited. 